\title{
A Preliminary Study on Some Reproductive Traits and Heterosis Effects of Anglo Nubian and Etawah Grade Crossbred Does
}

\author{
Praharani L, Supriyati, Krisnan R \\ Indonesian Research Institute for Animal Production \\ PO Box 221, Bogor 16002, West Java, Indonesia \\ lisa_praharani@yahoo.com
}

\begin{abstract}
Demand of goat milk has been increasing, however, the milk production of local dairy goat, Etawah Grade (PE) is low. Crossbreeding was applied to increase milk production of PE. The objective was to evaluate reproductive traits and their heterocyst effects of F1 AN $\times \mathrm{PE}$ (NE) does. Records of 39 F1 NE, 23 AN and 24 PE does were used. The age at first kidding (AFK), postpartum estrus (PPE) and kidding interval (KI) were affected by genotypes $(\mathrm{P}<0.05)$. The number services to conception (NSC), litter size (LS) and gestation length (GL) were not different $(\mathrm{P}>0.05)$. The mean of AFK were 435.91 $\pm 3.62,460.95 \pm 4.30$ and $469.52 \pm 4.22$ days; the mean PPE were $46.62 \pm 1.66,43.92 \pm 1.97$ and $51.52 \pm 1.93$ days; the mean of $\mathrm{KI}$ were $257.85 \pm 2.05$, $262.21 \pm 2.44$ and $266.52 \pm 2.39$ days; the mean of NSC were $1.11 \pm 0.06,1.08 \pm 0.07$ and $1.16 \pm 0.07$, the mean of LS were $1.59 \pm 0.08,1.54 \pm 0.10$ and $1.46 \pm 0.09$; the mean of GL were $151.76 \pm 1.17$, $150.25 \pm 1.39$ and $150.36 \pm 1.37$ days for F1 NE, AN and PE, respectively. The heterocyst effect of AFK, PPE, KI, NSC, LS, GL were $6.30,1.27,2.47,0.40,6.0,-0.97 \%$, respectively. The F1 $\mathrm{AN} \times \mathrm{PE}$ crossbred does showed better reproduction performance than PE due to heterocyst effects caused by crossbreeding. The results of this study were an information base of the reproductive characteristics of F1 NE does used to improving their reproductive efficiency.
\end{abstract}

Key Words: Crossbreeding, Heterocyst Effect, Reproduction, Anglo Nubian, Goats

\section{INTRODUCTION}

Goat milk has been favorable for consumption like cow milk, even for infant. It has been well-known that goat milk has several medicinal values as therapeutic virtues for dietetic and ulcers problems or people allergic to cow milk and inflammatory diseases (Kumar et al. 2012; Asresie \& Adugna 2014). Therefore, people are willing to pay higher for goat milk than cow milk, in many countries (Kosgey et al. 2013).

Increasing goat milk is through genetic improvement either by selection or crossbreeding. Crossbreeding has been used for a number of reasons including the benefit of heterocyst, as an initial stage for the development of a new (composite) breed (Bourdon 2000). The option of crossbreeding to introduce suitable genetic material for milk production is a much more rapid method than by selection. Heterocyst, also referred to as hybrid vigor, is the better performance than the average of the parent breeds of a crossbred animal. In General, the value of heterocyst in production traits range from $0-10 \%$, whereas fertility and reproductive traits from 5-25\% (Bondoc 2005). Many crossbreeding program in dairy goat has been done to increase goat productivity and milk yield (Assan 2013; Norberg et al. 2014).

Reproductive efficiency is an important pre-condition for increasing production potential in any given environment. Reproduction performance of females such as fertility, gestation length, age of first kidding, kidding interval are important factors affected production efficiency (Bhowmik et al. 2014). The profitability of goat production depends primarily on the efficiency of female productivity. Improving female's reproductive performance by selection is difficult due to its low heritability (García-Peniche et al. 2012) 
indicating that the possibility for genetic improvement through selection is limited, therefore, crossbreeding can be used to quickly improve reproductive performance via its resultant yield of heterocyst (Hassan et al. 2007) and reproductive (Magaña \& Correa 2001). However Nguluma et al. (2013) reported that crossbreeding did not improve reproduction performance of local goats.

The Etawah grade, a local goat breed, is one of the dairy goat breed in Indonesia. They have been well-known for their adaptability in harsh environment, thus it is suitable to smallholder and most farmers like to raise them. However, their milk production is still low ranged 0.2-1.2 litres/head/day (Sutama 2014; Praharani 2014a). Introduction of Anglo Nubian for improving milk production has been done in Indonesian Research Institute for Animal Production crossed to Etawah Grade does since 2012. Anglo Nubian was known for good milk production with the highest milk fat, and favorable to tropical climate region due to their better adaptability to tropical condition (Stemmer et al. 2009; Lallo et al. 2011). First crossbred kids were born in 2013 and have been observed their productivity. Praharani (2014b) and Praharani et al. (2014c) reported that growth rate from birth to puberty of F1 AN $\times$ PE was higher than Etawah Grade.

The objective of this study was to evaluate some reproductive traits and their heterocyst effects of F1 AN $\times \mathrm{PE}$ does. This study might be used as early information for recommendation in increased local goat milk using exotic breed such as Anglo Nubian.

\section{MATERIAL AND METHODS}

This study was carried out in Goat Research Unit at Research Institute for Animal Production, Bogor. It is located at about $450 \mathrm{~m}$ above sea level with rainfall of 4000 mm/year.

A total of 86 does consisted of $39 \mathrm{~F} 1 \mathrm{AN} \times \mathrm{PE}, 23 \mathrm{AN}$ and $24 \mathrm{PE}$ were used in this study. Does were at the age of 7-8 months and weighing 25-30 kg. All animals were put in a group of 5-6 animals/group. Bucks with excellent libido and of known fertility were joined to the does. Trained personnel observed the signs of estrus twice a day for 30 minutes $(7: 00,13: 00)$. The doe was considered in estrus when it showed estrous signs indicated by waggling its tail, bleating, mounting others and/or allowed the bucks or other goats to mount her (Hafez 2000). The doe was considered pregnant when it did not show estrus after mating. The pregnant doe was kept separately in individual pen until kidding. Kid and doe were kept together for colostrum's and separated after one week. All does were mated after showing the second post-partum estrus sign.

The animals were raised in the same management system. Goats were fed 3-4 $\mathrm{kg}$ of King Grass or about $10 \%$ of body weight. They were also offered a commercial concentrate $(400-500 \mathrm{~g} / \mathrm{head} / \mathrm{day})$ containing on average $16-17 \%$ crude protein and $70 \%$ TDN about 2-3\% of body weight or 200-300 gram of legumes mixture containing Gliricidae sp, Caliandra, Leucaena leucocephala were available for animals in the pen. Water was provided ad libitum. The pregnant does were additional fed tofu cake byproduct of 250 gram/doe/day.

Parameters observed were numbers of services to conception (NSC), gestation length (GL), litter size (LS), age at first kidding (AFK), kidding interval (KI) and post-partum estrus (PPE). Numbers of services to conception was defined as how many times doe had been mated until they were pregnant. Gestation length was measured from mating until kidding. Post-partum estrus was the day when the first estrus came after kidding. Postpartum estrus was observed when the does showed over estrus signs. Kidding interval was determined numbers of days between first and second kidding. 
All data were analyzed using general linear model (SAS 2003). The independent variable was genotypes, while the dependent variables were NSC, GL, LS, AFK, KI and PPE. P-Diff was used to test the differences of traits observed among genotypes. Heterosis effect was calculated using equation bellow:

$$
\begin{aligned}
& \mathrm{HE}=\left(\mathrm{P}_{\mathrm{NE}}\left(\left(\mathrm{P}_{\mathrm{AN}}+\mathrm{P}_{\mathrm{PE}}\right) / 2\right)\right) /\left(\left(\mathrm{P}_{\mathrm{AN}}+\mathrm{P}_{\mathrm{PE}}\right) / 2\right) \times 100 \% \text {, where } \\
& \mathrm{HE}: \text { heterocyst effect } \\
& \mathrm{P}_{\mathrm{NE}}: \text { reproductive trait observed of } \mathrm{F} 1 \mathrm{AN} \times \mathrm{PE} \\
& \mathrm{P}_{\mathrm{AN}}: \text { reproductive trait observed of } \mathrm{AN} \\
& \mathrm{P}_{\mathrm{PE}}: \text { reproductive trait observed of } \mathrm{PE}
\end{aligned}
$$

\section{RESULTS AND DISCUSSION}

\section{Reproductive characteristics}

Age at first kidding is defined as the age at which does kid for the first time. Age at first kidding is an important factor in determining life time productivity. The earlier the doe starts to kid the better her production performance meaning longer time for her to stay in the flock. There is a big variation in age at first kidding among the production systems and breeds.

The overall means and standard deviation of age of first kidding was $453.27 \pm 25.62$ days with ranged between $390-500$ days and $4.65 \%$ (Table 1). This result was in agreement of some literature stated that age of first kidding in goats ranged between 321534 days including local and exotic breed (Sutama et al. 2011; Patel \& Pandey 2013; Budisatria \& Udo 2013; Bhowmik et al. 2014; Dereje et al. 2015). The pooled data of Saanen, Toggenburg, Anglo Nubian and La Mancha in USA dairy goats showed that age of first kidding was 507.97 days (Castañeda-Bustos et al. 2014).

Following parturition, livestock must undergo numerous physical and hormonal changes in order for reproductive function to be restored. Uterine involution and resumption of ovarian activity must be achieved for the resumption of reproductive function resulted in first estrus after partus (Senger 2003). Post-partum estrus ranged between 31-71 days with average of $47.31 \pm 10.01$ days and variation of $20.44 \%$ (Table 1 ). This result was in agreement of some literature stated that post-partus estrus of goats ranged between 23-74 days (Freitas et al. 2004; Sutama et al. 2011; Budisatria \& Udo 2013; Yagoub et al. 2013; Bhowmik et al. 2014).

Table 1. Descriptive statistics for the reproductive traits analyzed across genotypes

\begin{tabular}{lrrrrrc}
\hline \hline Traits & N & Means & Min & Max & $\begin{array}{c}\text { Standard } \\
\text { deviation }\end{array}$ & $\begin{array}{c}\text { Coefficient } \\
\text { variation }\end{array}$ \\
\hline AFK, days & 86 & 453.27 & 390 & 500 & 25.62 & 4.65 \\
PPE, days & 86 & 47.31 & 31 & 71 & 10.01 & 20.44 \\
KI, days & 74 & 261.72 & 237 & 300 & 12.35 & 4.56 \\
NSC & 86 & 1.12 & 1 & 3 & 0.57 & 32.67 \\
LS & 86 & 1.51 & 1 & 3 & 0.50 & 33.65 \\
GL, days & 74 & 150.90 & 146 & 156 & 2.14 & 4.53 \\
\hline
\end{tabular}

AFK: Age at first kidding; PPE: Post partum estrus; KI: Kidding interval; NCS: Numbers of services to conception; LS: Litter size; GL: Gestation length 
Kidding interval is an important trait in animal production due to its effect on animal population turnover rate and total lifetime productivity. Kidding interval ranged between 237-300 days with average of $261.72 \pm 12.35$ days and variation of $20.44 \%$ (Table 1 ). Some literatures showed kidding interval for different goat breeds was similar to this study (Budisatria \& Udo 2013; Yagoub et al. 2013; Abdalla et al. 2015).

The descriptive statistics for the traits evaluated are shown in Table 1. The overall means of numbers of services to conception was $1.12 \pm 0.57$, with ranged between 1-3 and high variation of $43.35 \%$. This result was in agreement of some literature stated that numbers of services to conception of goats ranged between 1-2.75 (Sutama et al. 2011; Abdullah et al. 2012; Parasmawati et al. 2013; Abdalla et al. 2015).

Litter size or number of kids in the litter is the total number of kids born per kidding per goat indicating doe fertility influenced by genetics (Hafez 2000). Litter size is an important factor which determines the reproductive efficiency of the farm (Tsukahara et al. 2011). The overall mean of litter size was $1.51 \pm 0.50$, ranged between $1-3$ and variation $33.65 \%$ (Table 1). This result was in agreement of some literature stated that litter size of goats ranged between 1-1.7 (Sutama et al. 2011; Mellado et al. 2011; Parasmawati et al. 2013).

The overall means of gestation length was $150.90 \pm 2.14$ days with ranged between 146-156 days and low variation of 4.53\% (Table 1). This result was in agreement of some literature stated that gestation length of goats ranged between 144-156 days (Sutama et al. 2011; Parasmawati et al. 2013; Patel \& Pandey 2013; Yagoub et al. 2013; Bhowmik et al. 2014).

\section{Genotype effects}

Genotype significantly affected age of first kidding $(\mathrm{P}<0.01)$ in this study similar to Dereje et al. (2015) found that there was breed differences in age of first kidding. The age of first kidding were $435.90 \pm 3.62,460.95 \pm 4.30$ and $469.52 \pm 4.22$ days for $\mathrm{F} 1 \mathrm{AN} \times \mathrm{PE}$, AN and PE, respectively (Table 2). The F1 $\mathrm{AN} \times \mathrm{PE}$ does had the youngest age of first kidding due to earliest reaching puberty as reported by Praharani et al. (2014c). It has also been stated by Praharani et al. (2014b) that F1 AN $\times$ PE grew faster and higher body weight, therefore, reaching puberty earlier than PE. Puberty in PE goat summarized by Sutama et al. (2011) was attained at 321-362 days of age, therefore age of first kidding might be at 471-512 days. In the present study, age of first kidding for PE was younger than Sutama et al. (2011). This difference of result might be due to different management resulted in different body weight.

Table 2. The least square means (LSMeans), stardard error and P-value from different genotypes

\begin{tabular}{lrrrrr}
\hline \hline \multirow{2}{*}{ Parameters } & P-Value & \multicolumn{3}{c}{ Genotypes } & \multirow{2}{*}{$\begin{array}{c}\text { Heterosis } \\
\text { F1 AN } \times \text { PE }\end{array}$} \\
\cline { 3 - 5 } & & \multicolumn{1}{c}{ AN } & \multicolumn{1}{c}{ PE } & 6.30 \\
\hline AFK, days & 0.0001 & $435.90^{\mathrm{a}} \pm 3.62$ & $460.95^{\mathrm{b}} \pm 4.30$ & $469.52^{\mathrm{b}} \pm 4.22$ & 1.27 \\
PPE, days & 0.0215 & $46.62^{\mathrm{a}} \pm 1.66$ & $43.92^{\mathrm{a}} \pm 1.97$ & $50.52^{\mathrm{b}} \pm 1.93$ & 2.47 \\
KI, days & 0.0231 & $257.85^{\mathrm{a}} \pm 2.05$ & $262.25^{\mathrm{ab}} \pm 2.44$ & $266.52^{\mathrm{b}} \pm 2.39$ & 0.40 \\
NCS & 0.7639 & $1.11 \pm 0.06$ & $1.08 \pm 0.07$ & $1.16 \pm 0.07$ & 6.00 \\
LS & 0.2102 & $1.59 \pm 0.08$ & $1.54 \pm 0.10$ & $1.42 \pm 0.09$ & -0.97 \\
GL, days & 0.6396 & $151.76 \pm 1.17$ & $150.25 \pm 1.39$ & $150.36 \pm 1.37$ & \\
\hline
\end{tabular}

AFK: Age at first kidding; PPE: Post partum estrus; KI: Kidding interval; NCS: Numbers of services to conception; LS: Litter size; GL: Gestation length; ${ }^{\mathrm{a}, \mathrm{b}}$ different superscript in the same row differ significantly at $\mathrm{P}<0.05$ 
Post-partum estrus $(\mathrm{P}<0.05)$ was influenced by genotype. This results were similar to some findings that post-partum estrus were affected by genotypes or breed of goats (Freitas et al. 2004). Least squares means of Post-partum estrus were 46.62 \pm 1.66 , 43.92 \pm 1.97 and $50.52 \pm 1.93$ days for $\mathrm{F} 1 \mathrm{AN} \times \mathrm{PE}, \mathrm{AN}$ and $\mathrm{PE}$, respectively (Table 2). The PE goats showed a longer first estrus after partus than F1 AN $\times$ PE and AN, however postpartum estrus of F1 AN $\times$ PE and N were no different. A review (Sutama 2014) mentioned that first estrus after kidding in PE goat showed at 3-5 months because does and kids stayed together until weaning. In this study, post-partus estrus showed faster than Sutama et al. (2011), because does and kids were separated after kidding. This study was similar to those reported that in Saudi Arabia, Anglo Nubian showed first estrus after kidding at 51.0 \pm 4.5 days (Yagoub et al. 2013), and in Sudan 57.8 \pm 21.5 days (Hassna et al. 2013). Post-partum estrus can be influenced by feeding management including quantity and quality of forages and concentrates. Good feeding management can resulted for earlier post-partum estrus.

Kidding interval was influenced by genetic $(\mathrm{P}<0.05)$. Kidding interval were $257.85 \pm 2.05,262.25 \pm 2.44$ and $266.52 \pm 2.39$ for $\mathrm{F} 1 \mathrm{AN} \times \mathrm{PE}$, AN and PE, respectively (Table 2). The PE does showed longer kidding interval compared to F1 AN $\times$ PE and AN. This finding were higher than those reported by Yagoub et al. (2013) that Nubian goats raised extensively in Sudan showed 240 days and in of kidding interval. Lallo et al. (2013) stated that Anglo Nubian is suitable raised in the tropical area indicated by their fertility and shorter kidding interval.

The least square means (LS Means), standard error and P-value from different genotypes are shown in Table 2. Genotype did not affect numbers of services to conception with $\mathrm{P}=76 \%$ in this study. These results were similar to some findings that number of services to conception was affected by genotypes or breed of goats (Parasmawati et al. 2013). Range was 1.01-1.23. About 8-16\% of does observed were mated $>1$ time. Sutama et al. (2011) reported that low pregnancy rate (60-73\%) of PE does when mating in the first estrous usually resulted in low pregnancy rate numbers of services to conception >1.4. The number of services to conception of PE was lower to those reported by Sutama et al. (2011). While Abdalla et al. (2015) stated that number of services to conception in Nubian raised in Sudan was $1.53 \pm 0.12$ which was higher than this study due to different breed and management system. However, in this study, all does showed no difference in number of services to conception indicated high fertility.

Litter size was not affected with probability $21 \%$ by genotype (Table 2). Range of litter size was 1.33-1.67. This results were similar to some findings that litter size were not affected by genotypes or breed of local goats in Ethiopia (Dereje et al. 2015) and PE goats (Parasmawati et al. 2013). In Mexico, Anglo Nubian showed litter size 1.56 \pm 0.5 (Mellado et al. 2011) similar to this present study. Other study mentioned that Anglo Nubian, in Sudan, showed litter size of $1.75 \pm 0.71$ (Hassna et al. 2013) higher than this study. Sutama et al. (2011) had reported that litter size of PE goats was 1-1.04 that will increase to 1.3-1.6 as parity increased. The litter size of PE goats in this present study was lower to those reported by Sutama et al. (2011) due to different management and environment.

Genotype did not affect gestation length with probability $64 \%$ in this study. Gestation length range was 148.86-152.93 (Table 2). This result was similar to some findings that gestation length was not affected by genotypes or breed of goats (Parasmawati et al. 2013). The gestation length in this study closed to those reported by Sutama et al. (2011) found in PE goats between 144-156 days and Yagoub et al. (2013) mentioned Anglo Nubian had gestation length of 147.1 \pm 0.8 days in Saudi Arabia and 152.3 \pm 5.4 in Sudan (Hassna et al. 2013). 


\section{Heterosis effects}

There were only a few number reports of heterocyst effect for reproductive traits in dairy goats. In a comprehensive review of crossbreeding studies in goats worldwide, Bondoc (2005) found that heterocyst of some reproductive traits from 30 goat breeds was low and sometimes negative. The average heterocyst is only $6.4 \%$ collected from some reproductive traits such as age of first estrus, mating, kidding; conception rate, dry period, gestation length, kidding interval, kidding rate, twinning, service per conception (Bondoc et al. 2001). Effect of heterocyst for reproductive traits in this study ranged between -0.97 and $6.30 \%$ closed to the reviewed by Bondoc et al. (2001).

The age at first kidding had highest heterocyst effect $(6.30 \%)$ which indicated that F1 $\mathrm{AN} \times \mathrm{PE}$ had earlier age at first kidding than the average of parents meaning performance due to crossbreeding effect. Gestation length had lowest heterocyst effect $(-0.97 \%)$. The negative heterocyst effect showed that crossbred does performed lower than the average parents, however the value of heterocyst effect was very small. Crossbreeding improved kidding interval becoming shorter than $\mathrm{PE}$ due to heterocyst effect of $6 \%$ similar to Magana \& Correa (2001) reported that heterocyst of calving interval in Zebu crossbred was $6.5 \%$.

Heterocyst effect of post-partus estrus was $1.27 \%$ although it was small value, heterocyst effect made post-partus estrus for crossbred does showed earlier than the PE. The numbers of services to conception had low heterocyst of $0.40 \%$. Crossbreeding did not improve much the numbers of services to conception that was indicated by no genotype effect. The crossbreds had similar value of number of services to conception to the average of their parents.

Crossbreeding effect on litter size had been showed in $\mathrm{F} 1 \mathrm{AN} \times \mathrm{PE}$ having higher heterocyst effect of $6 \%$. Some literatures mentioned that heterocyst of litter size ranged between 7\% and 13\% (Zaman et al. 2002). In Jamunapuri and Black Bengal crossbred raised in Bangladesh, heterocyst of litter size was $15.48 \%$, higher than in the present study. Kantanamakul et al. (2011) reported that heterocyst of number kid born in AngloNubian and Native goat crossbred in Philippine was $11 \%$, higher that was higher than this present study. The difference among results was due to different breed and environments.

Crossbreeding may cause an effect of combination between genes of a character both quantitative and qualitative resulted from hetero-genetic. The value of heterocyst effect can be positive or negative, usually noted in either decimal numbers or percentage. Heterocyst effect was divided into individual (direct) heterocyst, maternal heterocyst and paternal heterocyst. The positive heterocyst effect indicated that the average performance of crossbred offspring exceeded the average performance of the parents. While, the negative heterocyst effect indicated that the average performance of crossbred offspring were lower than the average performance of parents. The level of heterocyst effect was influenced by genetic distance between breeds, the farther genetic distance the greater heterocyst effect becomes (Thepparat et al. 2012). However, heterocyst effect was also influence by environment and interaction of genetic and environment. According to Thepparat et al. (2012), the magnitude of heterocyst effect was largely dependent on the amount of homozygous recessives gen, the degree of dominance in which heterozygous exceed both homozygotes, and the level of epistatic interaction between non-allelic gene pairs.

\section{CONCLUSION}

Genotype affected age of first kidding, post-partum estrus and kidding interval. Positive heterocyst effects were shown on numbers of services per conception, age of first 
kidding, post-partum estrus and kidding interval and litter size. It can be concluded that $\mathrm{AN} \times \mathrm{PE}$ crossbred does showed better reproduction performance than PE due to heterocyst effects caused by crossbreeding.

\section{REFERENCES}

Abdalla SA, Ishag IA, Ahmed M-KA. 2015. Genetic and environmental factors affecting reproduction of Saanen goats raised under Sudan conditions. Am J Agric Sci. 2:75-79.

Abdullah R, Salleh MS, Wan Khadijah WE, Mavrogenis AP. 2012. Reproductive, production and economic performances of the Damascus (Shami) Goats in Cyprus. Proceedings of the 1st Asia Dairy Goat Conference, Kuala Lumpur, Malaysia, 9-12 April 2012. p. 106-107.

Assan N. 2013. Crossbreeding as a strategy to increase productivity in resource poor goat keepers in the rural areas of Zimbabwe. Int J Sci Knowl. 2:52-56.

Asresie A, Adugna M. 2014. Bioactive properties of goat milk: It's Hypoallergenic, nutritional and therapeutic significance: A Review. Global J Anim Sci Res. 2:315-320.

Bhowmik N, Mia MM, Rahman MM, Islam S. 2014. Preliminary study on productive and reproductive performances of Jamunapari, Black Bengal and Crossbred Goats at Chittagong Region of Bangladesh. Iran J App Anim Sci. 4:89-93.

Bondoc OL. 2005. The Philippine goat breed registry in relation to genetic improvement and conservation. The Phil Agric Sci. 88:179-191.

Bondoc OL, Santiago Cat, Tec JDP. 2001. Least-square analysis of published heterosis estimates in farm animals. Phil J Vet Anim Sci. 27:12-26.

Bourdon RM. 2000. Understanding animal breeding. New York (USA): Prentice Hall.

Budisatria IGS, Udo HMJ. 2013. Goat-based aid programme in Central Java: An effective intervention for the poor and vulnerable?. Small Rum Res. 109:76-83.

Castañeda-Bustos VJ, Montaldo HH, Torres-Hernández G, Pérez-Elizalde S, Valencia-Posadas M. 2014. Estimation of genetic parameters for productive life, reproduction, and milk-production traits in US dairy goats. J Dairy Sci. 97:2462-2473.

Dereje T, Mengistu U, Getachew A, Yoseph M. 2015. A review of productive and reproductive characteristics of indigenous goats in Ethiopia. Livest Res Rur Dev. 20:27-33.

Freitas VJF, Rondina D, Nogueira DM, Simplı́cio AA. 2004. Post-partus anoestrus in AngloNubian and Saanen goats raised in semi-arid of North-eastern Brazil. Livest Prod Sci. 90:219226.

García-Peniche TB, Montaldo HH, Valencia-Posadas M, Wiggans GR. 2012. Breed differences over time and heritability estimates for production and reproduction traits of dairy goats in the United States. J Dairy Sci. 95:2707-2717.

Hafez ESE. 2000. Reproduction in farm animals. Philadelphia (USA): Lea and Febiger.

Hassan MM, Mahmud SMN, Islam SKM. 2007. A comparative study on reproductive performance and productivity of the Black Bengal and Crossbred goat at Atrai, Bangladesh. Univ J Zool Rajshahi Univ. 26:55-57.

Hassna AE, Nikhaila A, Khalid AM. 2013. Effect of natural suckling on postpartus reproductive performance of Nubian Goats. U of K. J Vet Med Anim Prod. 4:53-59.

Kosgey IS, Owuor G, Chelanga PK. 2013. Consumer willingness to pay for dairy goat milk in Siaya County, Kenya. Livest Res Rur Dev. 25:1-10.

Kumar S, Kumar B, Kumar R, Kumar S, Khatkar SK. 2012. Nutritional features of goat milk, a review. Indian J Dairy Sci. 65:266-273. 
Magaña JG, Correa JCS. 2001. Estimates of breed and heterosis effects for some reproductive traits of Brown Swiss and Zeburelated breeds in Southeastern Mexico. Livest Res Rur Dev. 13:1-10.

Mellado M, Meza-Herrera CA, Arévalo JR, De Santiago-Miramontes MA. 2011. Relationship between litter birth weight and litter size in five goat genotypes. Anim Prod Sci. 51:144-149.

Nguluma A, Leite-Browning ML Browning R Jr. 2013. Comparison of Boer Cross and foundation breeds for meat goat doe fitness in the humid subtropics. Livest Res Rural Dev. 25:1-11.

Norberg E, Sørensen LH, Byskov K, Kargo M. 2014. Heterosis and breed effects for milk production, udder health and fertility in Danish Herds applying systematic crossbreeding. Proceedings 10th World Congress of Genetics Applied to Livestock Production. Vancouver (Canada):

Parasmawati F, Suyadi, Wahyuningsih S. 2013. Performan reproduksi pada persilangan Kambing Boer dan Peranakan Etawah (PE) Jurnal Ilmu-Ilmu Peternakan 23:11-17.

Patel AC, Pandey DP. 2013. Growth, production and reproduction performance of Mehsana Goat. J Livest Sci. 4:17-21.

Praharani. 2014a. Milk yield of Anglo Nubian, Saanen $\times$ Etawah Grade and Etawah Grade raised in the same environment. In: Subandriyo, Kusmartono, Santosa KA, Kurnianto E, Purnomoadi A, Sodiq A, Wiryawan KG, Darodjah S, Inounu I, Darmono, Priyanti A, Wynn P, Han JL, Tay-Hsu J, Idrus Z, editors. Sustainable Livestock Production In The Prespective Of Food Security, Policy, Genetic Resources, And Climate Change. Proceedings of the $16^{\text {th }}$ Asian Australian Animal Production. 10-14 November 2014, Yogyakarta, Indonesia. Yogjakarta (Indonesia): In Collaboration with Ministry of Agriculture Faculty of Animal Sciences Universitas Gadjah Mada. p. 1527-1530.

Praharani L. 2014b. Evaluation On Growth Rate Of Anglo Nubian, Etawah Grade, And Anglo Nubian X Etawah Grade Kids. In: Wiryawan KG, Liang JB, Devendra C, Takahashi J, Orskov ER, Astuti DA, Manalu W, Jayanegara A, TjakradidjajaAS, Suharti S, Arief II, Evvyernie D, editors. Proceedings of 2nd Asian Australian Dairy Goat Conference. April 25-27 th $^{\text {2014, }}$ Bogor, Indonesia. Bogor (Indonesia): Bogor Agricultural University. p. 102-104.

Praharani L, Krisnan R, Budiarsana IGM. 2014c. Pengaruh heterosis pertumbuhan pra-pubertas pada kambing Anglo Nubian, Peranakan Etawah dan persilangannya. In: Kaiin EM, Chief in editor. Peran Bioteknologi dalam Peningkatan Populasi dan Mutu Genetik Ternak Mendukung Kemandirian Daging dan Susu Nasional. Seminar Nasional Bioresources Untuk Pembangunan Ekonomi Hijau. Bogor (Indonesia): Lembaga Ilmu Pengetahuan Indonesia. p. 427-434.

SAS. 2003. SAS User's Guide: Statistics. Cary (USA): SAS Inst., Inc.

Senger PL 2003. Pathways to pregnancy and parturition, 2nd ed. Pullman: Current Conceptions, Inc.

Sutama IK, Budiarsana IGM, Supryati. 2011. Perakitan kambing Sapera dengan produksi susu 2 liter dan pertumbuhan pasca sapih >100 g/hari. Laporan Akhir Program Insentif Riset Terapan Balitnak.

Sutama IK. 2014. Dairy goat production on smallholder agriculture in Indonesia. In: Wiryawan KG, Liang JB, Devendra C, Takahashi J, Orskov ER, Astuti DA, Manalu W, Jayanegara A, TjakradidjajaAS, Suharti S, Arief II, Evvyernie D, editors. Proceedings the 2nd AsianAustralian Dairy Goat Conference. April 25-27th 2014, Bogor, Indonesia. Bogor (Indonesia): Bogor Agricultural University. p. 8-20.

Stemmer A, Siegmund-Schultze M, Gall C, Zárate A. 2009. Development and worldwide distribution of the Anglo Nubian Goat. Trop Subtrop Agroecosyst. 11:185-188. 
Thepparat M, Duangjinda M, Tumwasorn S. 2012. Random heterosis effects on genetic parameters, estimation of birth weight, and Kleiber ratio in a population admixture of Thailand goats. Livest Sci 147:27-32.

Tsukahara Y, Oishi K, Hirooka H. 2011. Development and application of a crossbreeding simulation model for goat production systems in tropical regions. J Anim Sci. 89:3890-3907.

Yagoub MS, Alqurashi AM, Elsheikh AS. 2013. Some reproductive traits of female Nubian goats. J Am Sci. 9:385-389.

Zaman MR, Ali MY, Islam MA, Islam ABM. 2002 Heterosis on productive and reproductive performance of crossbreds from Jamunapari and Black Bengal goat crosses. Pakistan J Biol Sci. 5:94-96. 